\title{
Spatialized flood resilience measurement in rapidly urbanized coastal areas with a complex semi-arid environment in northern Morocco
}

\author{
Narjiss Satour ${ }^{1}$, Otmane Raji ${ }^{2}$, Nabil El Moçayd ${ }^{3}$, Ilias Kacimi ${ }^{1}$, and Nadia Kassou ${ }^{1}$ \\ ${ }^{1}$ Geosciences, Water and Environment Laboratory, Faculty of Sciences Rabat, Mohammed V University in Rabat, Morocco \\ ${ }^{2}$ Geology \& Sustainable Mining, University Mohammed 6 Polytechnic, Benguerir, Morocco \\ ${ }^{3}$ International Water Research Institute, University Mohammed 6 Polytechnic, Benguerir, Morocco
}

Correspondence: Narjiss Satour (narjiss.satour@gmail.com)

Received: 18 December 2019 - Discussion started: 17 January 2020

Revised: 10 February 2021 - Accepted: 16 February 2021 - Published: 25 March 2021

\begin{abstract}
Enhancing resilience is critical for coastal urban systems to cope with and minimize flood disaster risks. This issue is certainly more important in Africa, where the increase in flood frequency is a significant concern for many areas. In this context, urban planners need accurate approaches to set up a standard for measuring the resilience to floods. In Morocco, this issue is still not fully covered by the scientific community despite the obvious need for a new approach adapted to local conditions. This study applied a composite index and geographic-information-system approach to measure and map resilience to floods in three northern coastal municipalities. The approach is also based on a linear ranking of resilience parameters, offering a more optimal classification of spatial resilience variation. The results allowed us to identify specific areas with different resilience levels and revealed the relationship between urban dimensions and the flood resilience degree. This approach provides an efficient decision-support tool to facilitate flood risk management, especially in terms of prioritizing protective actions.
\end{abstract}

\section{Introduction}

Climate change is a major challenge for the development of African countries. Several studies have highlighted the severe impact of global change in Africa (Bates et al., 2008; CRED, 2019). The patterns of precipitation (Born et al., 2008; Giorgi and Lionello, 2008; Paeth et al., 2011), temperature (Fisher et al., 2015), and evapotranspiration (Speth et al., 2010) are more likely to change, which will alter the hydrological cycle in many regions, causing a change in the occurrence of extreme events such as drought and flooding, especially in arid and semi-arid areas (Karanja Ng'ang'a et al., 2016).

The coastal zones situated in semi-arid areas are considered to be among the most threatened areas by the increase in flood occurrence and rapid urbanization (Leal Filho et al., 2018). The impact of these floods particularly affects population concentrations. Consequently, as population growth increases, exposure to floods will be a real societal problem (Kundzewicz et al., 2014). Between 1993-2002, more than 19000000 persons have been affected by floods, and 9642 persons have died in Africa (Conway, 2009). Moreover, it is excepted that coastal African cities will experience a higher rate of population growth and urbanization over the 21st century (UN-Habitat, 2008; Lutz and Samir, 2010; Neumann et al., 2015). The rapid coastal development will exacerbate the already high vulnerability of many African coastal areas (Hinkel, 2011) since coastal cities are the most densely populated, with inhabitants taking advantage of residential, industrial, commercial, educational, and military opportunities (UN-Habitat, 2015).

Morocco, situated in the north-west of Africa, reveals a trend towards a decrease in average annual rainfall as well as an increase in average annual temperature (Hoffman and Vogel, 2008; Terink et al., 2013; El Moçayd et al., 2020). The intensity of floods will increase over time (Vicuña et al., 2011; Doocy et al., 2013; Roy et al., 2018), while the main economic activities are located in coastal zones, where $60 \%$ of the total Moroccan population is living (Snoussi et 
al., 2009). During recent years, several new policies have been implemented (Barthel and Planel, 2010; Ducruet et al., 2011; Kanai and Kutz, 2011) to improve these areas' economic growth and reduce the negative effect of rural migration. In this regard, the economy's main drivers are based on tourism and free-zone industries, which regrettably will increase the vulnerability of these zones to climate change (Perelli, 2018). Adaptation to climate change is an important factor to consider in order to achieve sustainability in such areas. As the combinations of environmental change, demographic growth, and urban-complexity challenges will put the urban environment under pressure (Marana et al., 2019), there are several ways to tackle adaptation issues, limiting the impact of a climate-related disaster, especially flooding (UNDRR, 2019). The classical methods proposed to deal with such issues involve implementing structural systems (Plate, 2002; Papadopoulos et al., 2017; Bertilsson et al., 2019). However, climate variability has a very substantial effect on the reliability of complex coastal-area systems. Therefore, adaptation should also focus on resilience (sustainabledevelopment goals) (Chen and Leandro, 2019; Miguez and Veról, 2016) rather than only structural measures. Resilience approaches aim to understand and manage a system's capacity to adapt, cope with, and shape uncertainty (Adger et al., 2005; Folke et al., 2002).

Since the work of Holling (1973), where the resilience concept originates from the ecology field, the concept has gained increasing interest and recognition (Cretney, 2014; Weichselgartner and Kelman, 2014; Patel et al., 2017; Kontokosta and Malik, 2018). The concept of resilience has been considered, in different ways, by various research fields: psychology (Westphal and Bonanno, 2007), geography (Pike et al., 2010; Cutter et al., 2010), archaeology (Redman, 2005), and physics (Cohen et al., 2000). Natural disasters, risk management, and climate change adaptation have recently been included (e.g. Godschalk, 2003; Cutter et al., 2008; Gaillard, 2010; Nelson et al., 2007; Serre et al., 2018).

Within the context of disasters and climate change, many definitions of the resilience concept have emerged. Some are focusing on the ability of the system, community, or city to absorb disturbances, retaining the same basic structures and normal ways of functioning, with self-organization capacity and adaption to stress and change (e.g. Pelling, 2003; Pendall et al., 2007; IPCC, 2007). Bouncing back to the original state (equilibrium) after a disaster is undesirable (Klein et al., 2003) knowing that social systems are in a continuous state of change. Adaptation to some changing trends or several states of equilibrium becomes one of the main characteristics of resilience depending on preparedness for the unprecedented and unexpected changes (Walker et al., 2004; Pendall et al., 2007; Paton et al., 2006; Ahern, 2011). This is determined by a system's capacity to organize itself, learn from past disasters, and improve risk reduction measures (UNISDR, 2016). Some works (e.g. Meerow et al., 2016) have linked the concept to the temporal and spa- tial scales, considering resilience to be the ability of urbansystem components (ecological and socio-technical) to maintain or rapidly return to desired functions.

Resilience has a systemic property and implies greater consideration of the temporal variability (Reghezza-Zitt et al., 2015). Some works describe it as the ability of short-term absorbing, self-organizing, and long-term learning and adaptation (e.g. Chen and Graham, 2011; Colding and Barthel, 2013). The current diversity in definitions makes it difficult to have a common concept (Carpenter et al., 2001). Therefore, a set resilience concept definition could be an appropriate basis.

In this work, the resilience of the urban system to floods is the capacity of flooded urban areas to maintain the activities during and after floods. Simply put, a resilient coastal urban area will be able to absorb the disaster (at an acceptable level) and be adapted to the changes. Besides, urban resilience is a complex and multidimensional concept (Sharifi and Yamagata, 2016); the resilience of the urban system to floods includes several dimensions of an urban system: social, economic, physical, natural, and institutional dimensions are equally important (Batica, 2015; Qasim et al., 2016). The social dimension explores flexibility, health status, and knowledge, while the economic dimension is related to the economic capacities, income resources, and connective devices within the community. The physical dimension may include urban density, building materials, and infrastructure (Qasim et al., 2016) and can be quantified based on physical indicators such as flood depth or flood duration extracted from flood simulation data (Mugume et al., 2015; Chen and Leandro, 2019). Areas located at low elevations or near rivers are more sensitive to flood disasters, constituting the natural component of resilience (Hung et al., 2016). Thus, institutions' efforts aim to cope with disasters through better planning; awareness programmes prefer integrated approaches by considering all these dimensions in the evaluation of resilience. It may help to have a global perspective, which will lead to creating suitable management tools that can be very useful in the decision-making process (Bertilsson et al., 2019). Supporting this decision-making process on strategies, actions, and measures to be taken and planning for the long, medium, and short terms as well as assessing the progress start with assessing the current and expected future status of resilience. This will highlight where resilient urban areas are and identify their strengths and weaknesses (Cardoso et al., 2020).

Because of its multidimensional aspect, quantifying resilience remains a great challenge (Bertilsson et al., 2019). Many works have shown the need to have some metrics able to measure resilience. However, to date, there is no consensus about a single metric evaluation, and the literature refers to the need for measures (e.g. Meerow et al., 2016; Asadzadeh et al., 2017; Rus et al., 2018). Furthermore, making resilience tangible and practical for cities through a transition from theory to practice is challenging (Kontokosta and Malik, 2018; 
Meerow et al., 2016). Quantitative approaches through composite indicators provide a synthetic measurement of a complex and multidimensional phenomenon (Chang and Jeon, 2014). Those indicators are developed based on the aggregation of multiple individual indicators (OECD, 2008). The choice of method to construct composite indices is dependent upon the type of problem, the nature of the data, and the goals (OECD, 2008). Several composite indices to assess the resilience of urban areas and compare their resilience levels within specific geographical regions have been proposed in recent years (e.g. Sharifi and Yamagata, 2016; Asadzadeh et al., 2017). For example, the work of Cutter et al. (2014) using BRIC (Baseline Resilience Indicators for Communities) is the first attempt at the operationalized version of the conceptual framework "DROP" (disaster resilience of place) model (Cutter et al., 2008). Within a socio-ecological approach, BRIC was calculated for a multi-hazard context. Among other analysts, Joerin et al. (2014) state that the CDRI (climate disaster resilience index) gauges the different capabilities needed for communities in an urban system to regain an equilibrium state after climate-related disasters such as cyclones, droughts, floods, and heatwaves. Following the same holistic spirit, this index was adopted in Climatic Hazard Resilience Indicators for Localities (CHRIL) (Hung et al., 2016). Mayunga (2007) also proposed a community disaster resilience index (CDRi). All of those previous indicators were applied to quantify community resilience to multiple natural hazards. Qassim et al. (2016) determined community resilience to a particular hazard, "floods", and specific community, "urban areas", as recently proposed also by Cariolet et al. (2019). However, many particular indicators were developed for a specific case of urban resilience to a specific hazard like floods.

Based on time-dependent characteristics, FResI (flood resilience index) was constructed to assess future resilience responses relative to the present situation (Miguez and Veról, 2016). Further, Chen and Leandro (2019) quantified the flood resilience of households in urban areas by the FRI (flood resilience index) as a time-dependent method. More examples of specific indicators are available (Kotzee and Reyers, 2016) using geographic information systems (GISs) and stress the need to move towards diversifying resilience assessment approaches.

Regardless of several challenges associated with data quality and availability constraint (Moghadas et al., 2019; Cai et al., 2018) and as a standard procedure for composite indicator development (Asadzadeh et al., 2017), particular attention has been paid to composite indicators (Heinzlef et al., 2019) regarding their ability to analyse the urban, social, and technical resilience of a city. However, a lack of resilience measurement tools developed by local authorities and organizations in the developing countries was reported in a critical review by Sharifi and Yamagata (2016).

The Mediterranean region will suffer from severe impact due to climate change (Tuel and Eltahir, 2020). Particularly
Morocco is mentioned as a hotspot for climate change in several works (Born et al., 2008; Driouech et al., 2009; Ouhamdouch and Bahir, 2017). Moreover, the precipitation's seasonal distribution strongly influences the Mediterranean river hydrology (Thornes, 2009). Assessing the intensity of the impact, regional-climate-model (RCM) simulations over this area all agree that Morocco might experience an increase in temperature and a decrease in precipitation (Driouech et al., 2010). This will have a severe impact on water (Bahir et al., 2020) and natural hazards (Satta et al., 2016), among others. Consequently, increasing resilience against flooding is, therefore, of utmost importance to achieve sustainability (Snoussi et al., 2008). However, a knowledge gap for a better understanding of resilience has been identified at national and local levels (Price, 2017) in Morocco. It is highly recommended to provide policymakers with a simple approach and ways to enhance resilience to floods in the local area (OCDE, 2016).

The present study is the first attempt to provide a methodological way to measure flood resilience for northern coastal municipalities in Morocco: Martil, M'diq, and Fnideq. In this work, flood resilience refers to the resilience of these coastal urban areas (Martil, M'diq, and Fnideq) to floods. These areas were selected because they show 18 hotspots highly exposed to floods (ABHL, 2016). Moreover, the area is particularly highly vulnerable to multiple hazard types, including floods (Karrouchi et al., 2016; Taouri et al., 2017), sea-level rise (Niazi, 2007; Snoussi et al., 2011), and coastal erosion (Satta et al., 2016; Nachite, 2009). However, the littoral is nowadays very urbanized, and tourist activities are the main economic resources in the area (Anfuso et al., 2010).

\section{Methods: study area and index development}

\subsection{Fnideq, M'diq, and Martil municipalities}

Related to the M'diq-Fnideq prefecture, the Fnideq, M'diq, and Martil municipalities have a population of 984 inhabitants $/ \mathrm{km}^{2}$ (RGPH, 2014). The precipitation regime is characterized by seasonality, with an annual average rainfall of $679 \mathrm{~mm}$ (ABHL, 2016). Rainfall variability is based on altitude and the geographic situation (Karrouchi et al., 2016). Rivers flowing into the Mediterranean Sea (Martil, Mellah, Smir, Negro, and Fnideq) drain slowly during the rainy months and intensely in a short time during flash floods (Niazi, 2007), while the frequency of flood events and related damages increased gradually over time (e.g. on 26 December 2000, Martil floods invaded more than 2400 ha in the Martil plain) (Fig. 1). Urbanization is concentrated in coastal zones and puts pressure on coastal ecosystems with high touristic value (Snoussi et al., 2011). It is pitiable that municipalities are also vulnerable to multiple climate and nonclimate hazards such as erosion and morphological changes (Satta et al., 2016). 


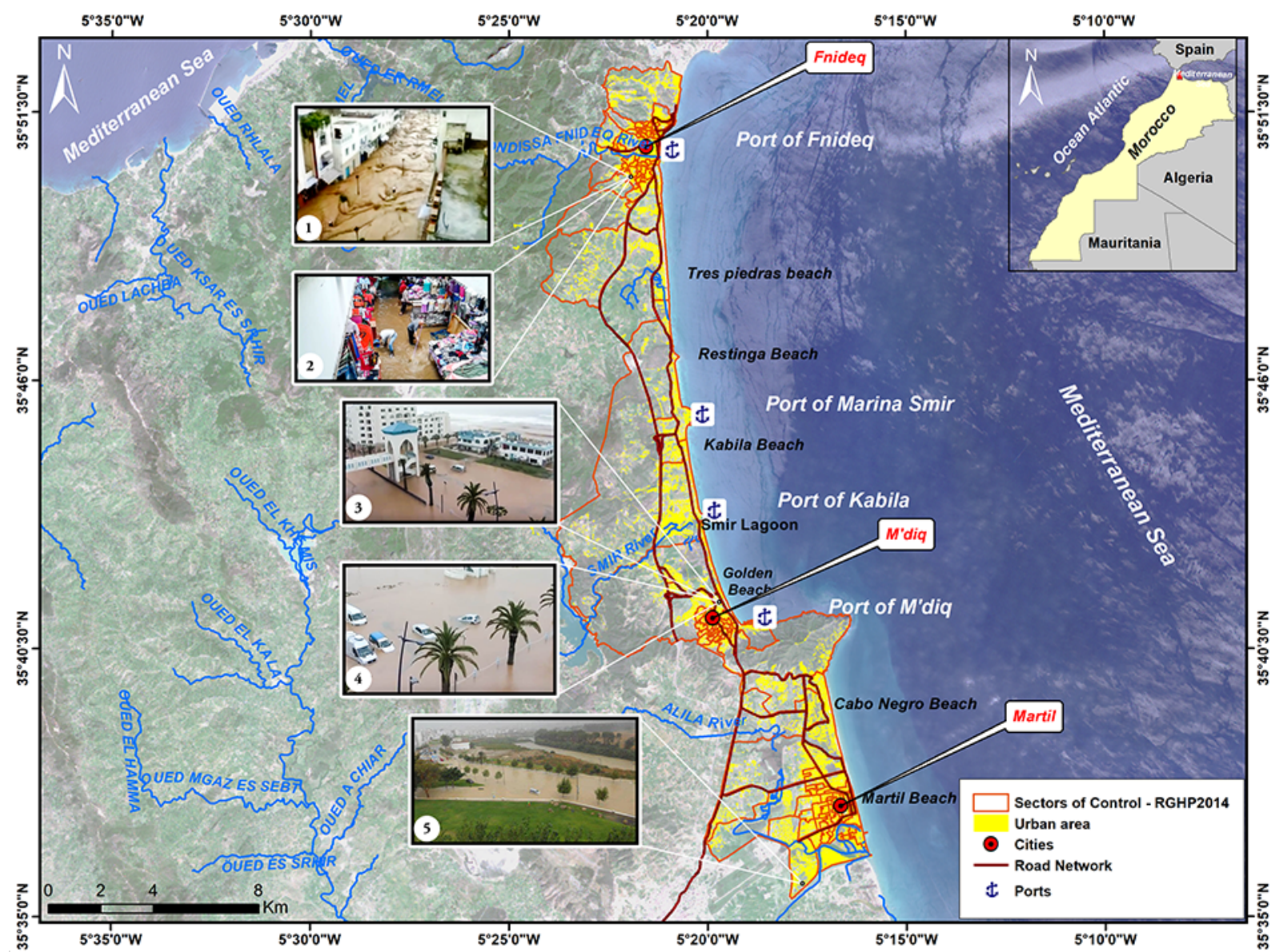

Figure 1. Location of the three studied municipalities: Fnideq, M'diq, and Martil, in northern Morocco, and examples of the flooding (1: photo of Fnideq centre on 28 September 2008; 2: photo of Almassira commercial centre Fnideqin on 27 September 2014; 3 and 4: photos of M'diq on 6 March 2010; 5: photo of Martil River on 2 March 2018). (C) Copernicus data (2017).

\subsection{Theoretical comprehensiveness for composite index development}

To produce an aggregate measure of resilience, through manipulation of individual variables, constructing a "composite indicator" is often undertaken. It is a mathematical combination of thematic sets of variables that represent different dimensions of a concept that cannot be fully captured by any individual indicator alone (OECD, 2008). An indicator is a quantitative or qualitative measure derived from observed facts revealing the relative position of the phenomena being measured. "It can illustrate the magnitude of change (a little or a lot) as well as the direction of change over time (up or down; increasing or decreasing)" (Cutter et al., 2010). Moreover, considerable attention is increasingly given to composite indices as useful tools for decision-making and public communication. They simplify and communicate easily the reality of complex situations (Freudenberg, 2003) and convey more precise information (Saisana et al., 2005). However, through different geographical contexts and scales, these indices may encompass many theoretical perspectives
(Cutter et al., 2008). Also, the quality of the framework, the data, and the used methodology can significantly influence a composite index's qualities and the soundness of the messages that it conveys.

The flood resilience index is explored and calculated differently in several works. Kotzee and Reyers (2016) used PCA (principal component analysis) as a method to construct this index and define its component weights. For Batica (2015) it has been built taking into account different spatial scales and focusing on urban functions. Using time series indicators (event phase and recovery phase), Chen and Leandro (2019) computed the FRI at time $t$ as the product of the recovery factor and the FRI at the previous time step $t-1$. By defining resilience as time-dependent, based on two phases (event and recovery), Leandro et al. (2020) have also shown the ability of the developed FRI for assessing climate change adaptation. Despite the already-existing studies on flood resilience assessment, there is still a need to develop methods for a specific case of study, where data availability remains a challenge, and the need for a tangible and simple way to better understand resilience is increasing. 


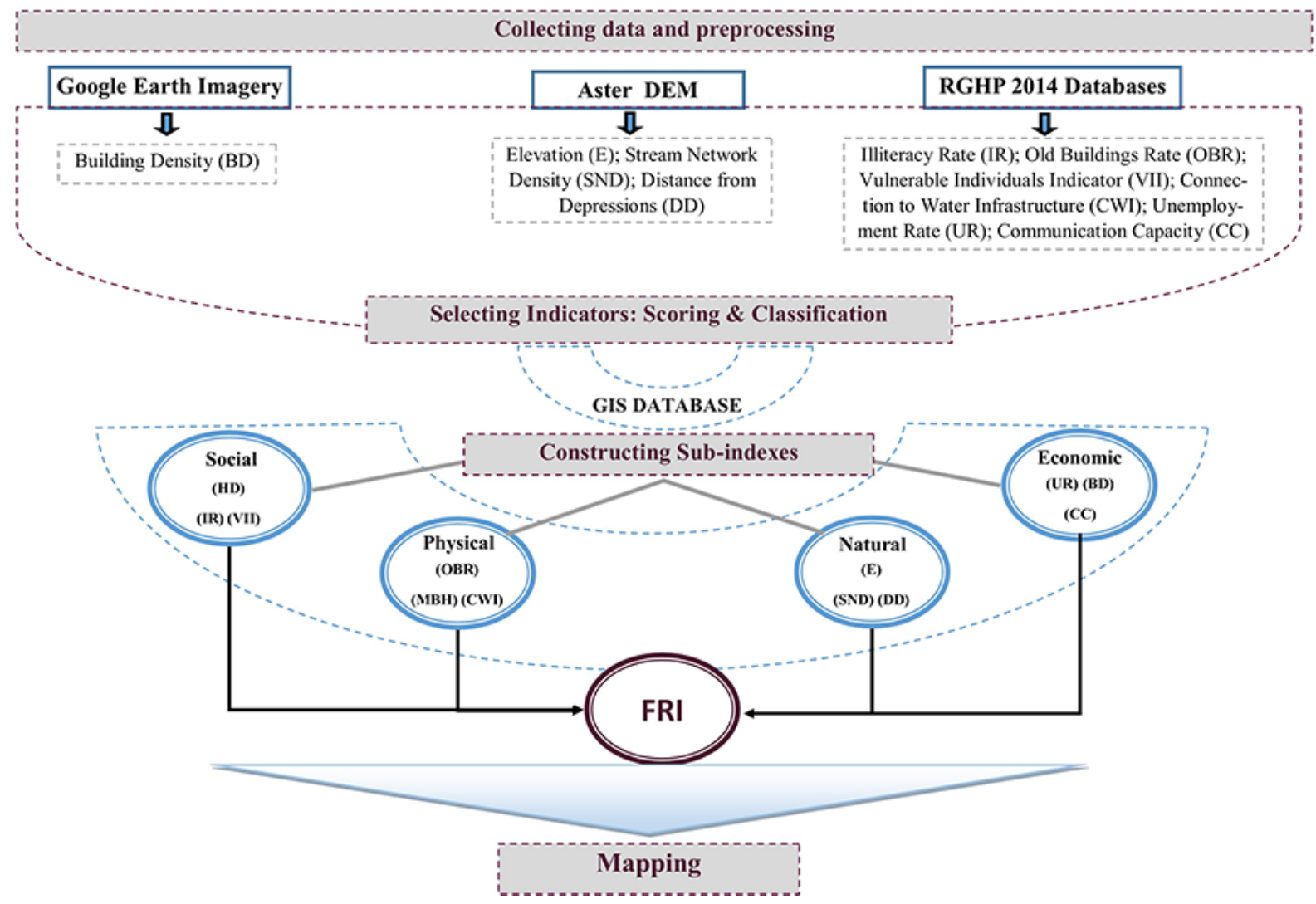

Figure 2. Procedure used to assess flood resilience in the three municipalities.

In this study, we adopt the specific flood resilience index to quantify the resilience of coastal urban areas to floods. The FRI was divided into four sub-indicators - social, physical, economic, and natural sub-indices - so as to enable sufficient flexibility to include or not each sub-index in the global composite index (Fig. 2). Three indicators were chosen for each sub-index (Table 1) based on data availability and their contribution to persistence, recovery, or adaptive capacity (the main components of the adopted resilience definition): household density (HD), illiteracy rate (IR), and the vulnerable-individual indicator (VII) were taken into consideration as the mean indicators that affect the social resilience negatively and construct the social sub-index. The physical sub-index included the old-building rate (OBR), the modernly built houses (MBHs), and the connection to water infrastructure (CWI). This sub-index is important because it improves the physical capacity of individual and common properties against floods and thus minimizes their vulnerability degree. The economic-resilience sub-index also includes three indicators: unemployment rate (UR), building density (BD), and communication capacity (CC). Finally, elevation (E), stream network density (SND), and distance from depressions (DD) are the indicators selected to determine the natural-resilience sub-index.

\subsection{Selecting indicators: scoring and classification}

Based on their relevance, analytical representativeness, and accessibility, 16 indicators (variables) were selected (Table 1). The data used were mainly drawn from the national population and housing census (RGPH, 2014). The Arc Hydro and Line Density modules of ArcGIS $@$ were used to generate a stream network density from an ASTER (Advanced Spaceborne Thermal Emission and Reflection Radiometer) digital elevation model ( $30 \mathrm{~m}$ of spatial resolution), while Google high-resolution satellite imagery was used for digitizing the building area. This was converted firstly into points, and then their density was calculated using the ArcGIS@ Point Density module.

\subsection{Normalization}

Indicators' integration into sub-indicators needs data normalization. Respecting the theoretical framework and the data characteristics, a min-max normalization was applied. Subsequently, each variable was normalized from 0 to $100 \mathrm{ac}$ cording to Eqs. (1) and (2): 
Table 1. Indicator descriptions selected to assess the flood resilience in the Fnideq, M'diq, and Martil areas (compiled from different sources).

\begin{tabular}{|c|c|c|}
\hline Dimensions & Indicators & Description of effect on resilience and justification \\
\hline \multirow[t]{3}{*}{$\begin{array}{l}\text { Social } \\
\text { (SD) }\end{array}$} & Household density (HD) & $\begin{array}{l}\text { Cities with higher building density in developing countries tend } \\
\text { to be densely populated, with many areas that have grown fast } \\
\text { (Andersson, 2006), often with insufficient infrastructure, } \\
\text { resulting in environmental degradation and high-damage floods. } \\
\text { Studies have found that highly resilient sites had low population } \\
\text { density (Sanabria-Fernandez et al., 2019). }\end{array}$ \\
\hline & Illiteracy rate (IR) & $\begin{array}{l}\text { This refers to the persons who have never learned to read. That can make } \\
\text { the emergency and public awareness processes challenging (Cutter } \\
\text { et al., 2010). }\end{array}$ \\
\hline & Vulnerable-individual indicator (VII) & $\begin{array}{l}\text { It refers to all vulnerable people (0-14-year-olds, } 60 \text {-year-olds, and } \\
\text { disabled people) who can create hindrances in mobility during } \\
\text { floods and operations of evacuation (Hung et al., 2016; Qasim et } \\
\text { al., 2016). }\end{array}$ \\
\hline
\end{tabular}

\begin{tabular}{|c|c|c|}
\hline \multirow[t]{3}{*}{$\begin{array}{l}\text { Physical } \\
\text { (PD) }\end{array}$} & Old-building rate (OBR) & $\begin{array}{l}\text { This is the percentage of buildings that are over } 50 \text { years old. It } \\
\text { expresses the fragility that increases with building material age. }\end{array}$ \\
\hline & Modernly built houses (MBHs) & $\begin{array}{l}\text { Based on the building material factor (by reinforced concrete and } \\
\text { bricks with mortar), modernly built houses will suffer less exterior } \\
\text { damage during flood events in the local state (Cutter et al., 2010). }\end{array}$ \\
\hline & Connection to water infrastructure (CWI) & $\begin{array}{l}\text { The high rate of connection to the sewage system and drinking water } \\
\text { distribution strengthens community resilience (Cutter et al., 2010). } \\
\text { Not being guaranteed access to water during and after } \\
\text { an emergency (Pagano et al., 2017) will aggravate the situation. }\end{array}$ \\
\hline \multirow[t]{3}{*}{$\begin{array}{l}\text { Economic } \\
(\mathrm{ED})\end{array}$} & Unemployment rate (UR) & $\begin{array}{l}\text { It expresses the decrease in the individual economic capacity. } \\
\text { Unemployed people are faced with difficulties related to their } \\
\text { disability to recover or rebuild their damaged property (Cutter et } \\
\text { al., 2010; Sherrieb et al., 2010). }\end{array}$ \\
\hline & Building density (BD) & $\begin{array}{l}\text { It reflects the concentration of buildings per area. For people more } \\
\text { concentrated in low-quality urban housing, infrastructure, and } \\
\text { services, the impact of a natural disaster is higher (Pallard et al., } \\
\text { 2009). It was selected based on the fact that an area with high } \\
\text { building density is less resilient to floods. }\end{array}$ \\
\hline & Communication capacity (CC) & $\begin{array}{l}\text { This is the rate of persons with communication devices (television, } \\
\text { mobile phone, and internet). The communication facilities' } \\
\text { availability during, after, and before flood hazards, strengthen } \\
\text { resilience (Cutter et al., 2010). }\end{array}$ \\
\hline \multirow[t]{3}{*}{$\begin{array}{l}\text { Natural } \\
\text { ND }\end{array}$} & Elevation $(\mathrm{E})$ & $\begin{array}{l}\text { It was selected based on the fact that lands with low elevation are } \\
\text { more at risk of flooding and exposed to damages compared to high- } \\
\text { elevation areas. }\end{array}$ \\
\hline & Stream network density (SND) & $\begin{array}{l}\text { It describes the degree of drainage network development and was } \\
\text { recognized to be significantly linked with the formation of flood } \\
\text { flows (Pallard et al., 2009). }\end{array}$ \\
\hline & Distance from depressions (DD) & $\begin{array}{l}\text { It expresses the distance from flood-prone areas or flood risk areas } \\
\text { (ABHL, 2016), including natural depressions of high flow accumulation. }\end{array}$ \\
\hline
\end{tabular}


$V^{+}=\left(\frac{\text { real value }- \text { minimum value }}{\text { maximum value }- \text { minimum value }}\right) \times 10$

$V^{-}=\left(1-\left(\frac{\text { real value }- \text { minimum value }}{\text { maximum value }- \text { minimum value }}\right)\right) \times 100$.

Equation (1) was applied for variables that positively influence resilience, while Eq. (2) was applied to those that are negatively correlated with resilience. When the scores are attributed, each of these indicators was gridded, and then a geodatabase was created to calculate the sub-indices by using the GIS. Each sub-index is the mean value of all correspondent indicators.

\subsection{Weighting and aggregation}

The existing methods for determining weights do not always reflect the priorities of decision-makers (Esty et al., 2005), which are subjective (Cutter et al., 2010). Equal weighting is the most common for composite indices with several subindicators (OECD, 2008). Thus, several arguments are listed by Greco et al. (2019) (i. simplicity of construction, ii. a lack of theoretical structure to justify a differential weighting scheme, iii. no agreement between decision-makers, iv. inadequate statistical and/or empirical knowledge, v. alleged objectivity). Moreover, the weighting method selection depends on the local factors where the method is applied (Mayunga, 2007; Reisi et al., 2014). Allocating equal importance across different indicators is better suited when no knowledge exists about the interactions among the sub-indicators and indices and the corresponding composite index at the local scale (Cutter et al., 2014; Asadzadeh et al., 2017). All variables are given equal weight (EW) in our case of study. The main reason is to allocate equal importance across indicators because of the lack of knowledge and justification about the existing interactions among the sub-indicators and composite index at the local level while avoiding a high concentration of a few indicators and making the composite index easy to communicate.

The simple method of aggregation, which is supposed to be transparent and easy to understand, is a critical criterion for potential users (Cutter et al., 2010). All individual indicators have the same measurement unit. Therefore, using linear aggregations is preferred over geometric aggregation. The linear aggregation formula of the FRI takes the following form:

$\mathrm{FRI}=\frac{\mathrm{SRI}+\mathrm{PRI}+\mathrm{ERI}+\mathrm{NRI}}{4}$,

where SRI is the social-resilience index, PRI is the physicalresilience index, ERI is the economical resilience index, and NRI is the natural-resilience index; 0 is considered to be a low resilience level, 100 a high resilience level, and 50 a medium resilience level.

\subsection{Links to other indicators}

To assess the correlation between the composite index and corresponding sub-indices and variables, a statistical analysis was performed using the program SPSS 23. Data presented as a mean and standard deviation (SD) were statistically analysed using multi-variance to confront data of natural, physical, economic, and social conditions with the flood resilience index and to identify which variables differ significantly between the three case study sites. The significant differences were distinguished by post hoc Tukey's honestly significant difference (HSD) test at $p<0.05$. The Spearman's $\rho$ coefficient was used for correlations between variables. Only significant correlation coefficients at a level of 0.05 are considered.

\subsection{Visualization and validation}

Particular attention has been paid to the visualization given its relevance in helping and enhancing interpretability. Maps facilitate further exploration of spatial data trends (Kotzee and Reyers, 2016). For that purpose, geographic information systems (GISs) were adopted to visualize the FRI and sub-indicators. After visualizing the composite index results, validation was the last step. Acting like a "quality assurance", this step will highly reduce the possibilities of conveying a misleading message (Saisana et al., 2005). Unfortunately such a step is often skipped for the vast majority of the composite indices (OECD, 2008). External validation has been the most used to validate several indicator results (CDRI 2009, BRIC 2012, CDRI 2013, and BRIC 2014).

In our case, the validation based on actual outcomes of the municipalities is possible using cross-validation type. It was performed to test and compare the reliability of FRI results using the results of other studies interested in hydro-climatic hazards as suggested by Satta et al. (2016). This is possible through the opposite correlation between risk and resilience (Cutter et al., 2014; Sherrieb et al., 2010). Seeking optimization by considering social and economic pathways, and combining flood resilience and flood risk, measures can be effective against a broader range of hazards than when considering either method alone (Disse et al., 2020).

\section{Results}

\subsection{Sub-indices}

Each sub-index was observed separately to get additional insights about the flood resilience index. The social resilience sub-index (Fig. 3d) was produced based on the three indicators of social resilience (Fig. 3a-c). The highest values of social resilience are more related to a few urban areas than rural and less developed sectors. In terms of mean value, the social-resilience sub-index was higher in Martil (69.03土 11.24), followed by Fnideq and the coastal area of M'diq, 

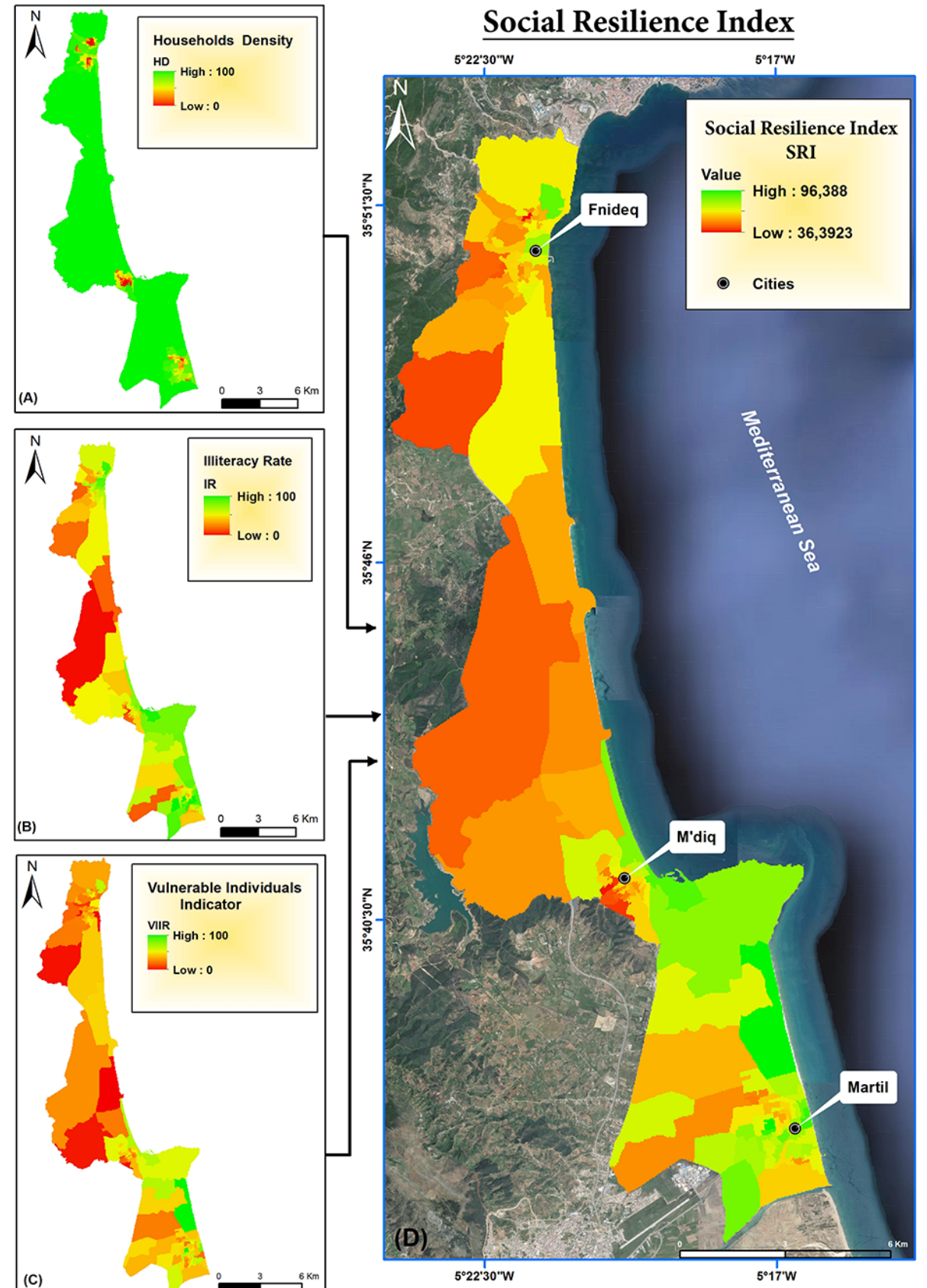

Figure 3. Spatial distribution of (a) household density, (b) illiteracy rate, (c) vulnerable-individual indicator, and (d) social-resilience index (obtained from (C) Google Maps 2018).

showing similar values $(57.11 \pm 9.26$ and $57.17 \pm 11.44$, respectively).

Higher physical-resilience scores (Fig. 4a-d) are concentrated in the urban-centre areas, with a spatial tendency towards the coastal area, even though pockets of lower scores exist in the central area and some less developed sectors, indicating low physical-resilience levels. Therefore, the central area had a somewhat low level of physical resilience as com- pared to the urban centres of Fnideq, M'diq, and Martil and the coastal zone (Fig. 4d).

Results (Fig. 5d) show a concentration of the low and moderate levels of economic resilience in the three urban centres. However, this does not exclude some coastal urban sectors showing high levels of the economic-resilience sub-index.

The overall map of the natural-resilience index shows a spatial variability between the lowest and the medium level of the NRI in the whole study area (Fig. 6d). However, the 

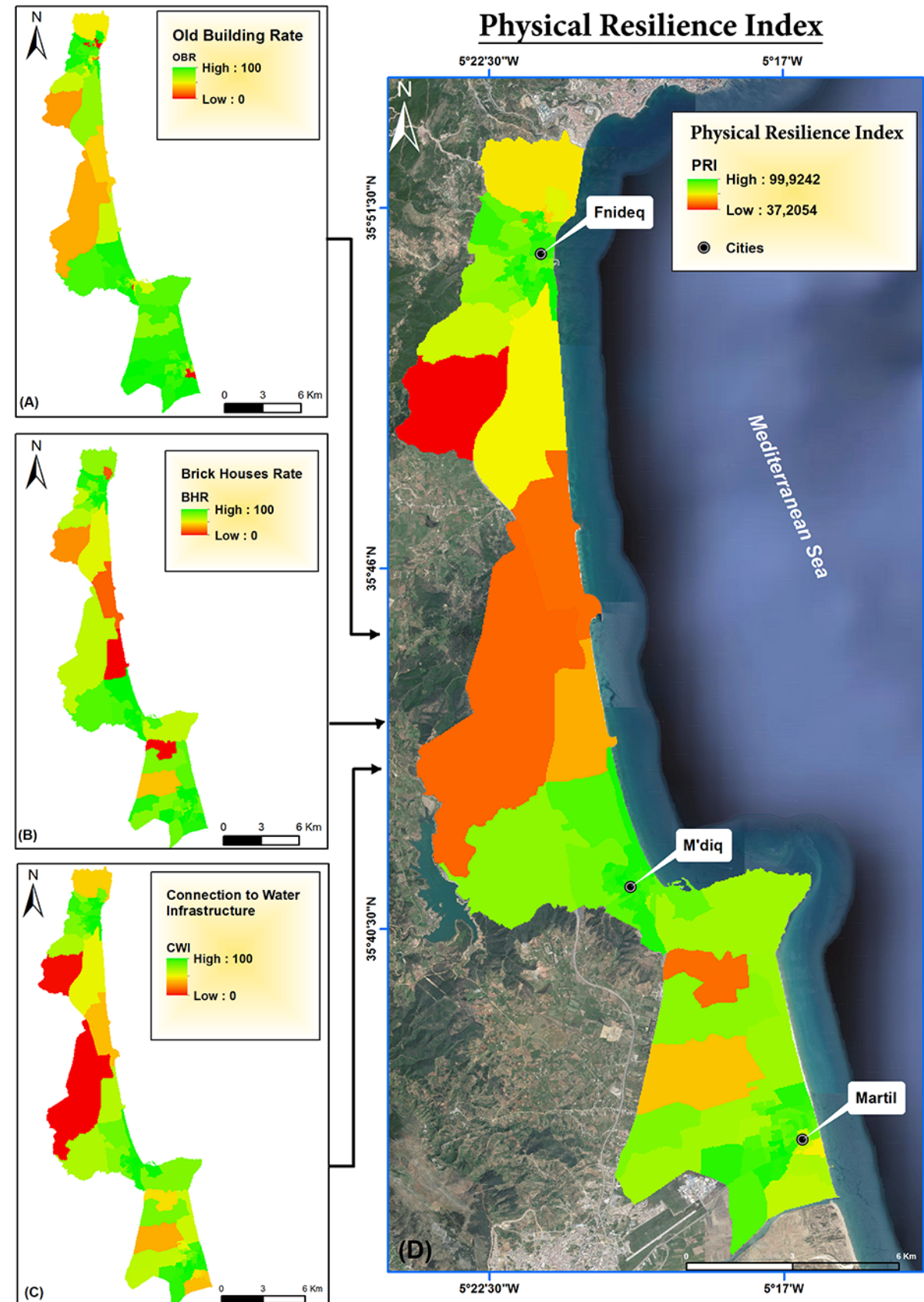

Figure 4. Spatial distribution of (a) old-building rate, (b) brick-house rate, (c) connection to water infrastructure, and (d) physical-resilience index (obtained from (C) Google Maps 2018).

high level of natural resilience is more prevalent in areas with high altitudes, such as Capo Negro (Fig. 6a and c).

\subsection{Total flood resilience index}

The results reveal a marked spatial variability in resilience to floods (Fig. 7). Overall, $31 \%$ of the study area varies from low to very low, which equals $45 \mathrm{~km}^{2}$ (Fig. 8a). A total of $43 \%$ of the studied area, which is equivalent to $52 \mathrm{~km}^{2}$, was classified as moderately resilient, and only $17 \%$ of the studied area $\left(17 \mathrm{~km}^{2}\right)$ was classified as highly resilient; the remaining $3 \%$ had very high resilience. The central area shows the lowest levels of the FRI, including sensitive coastal sites such as Smir lagoon, Kabila beach, and Restinga beach. In contrast, M'diq and the north of Martil have relatively moderate to high values in terms of resilience to floods. However, the significant disparities between rural and urban ar- 

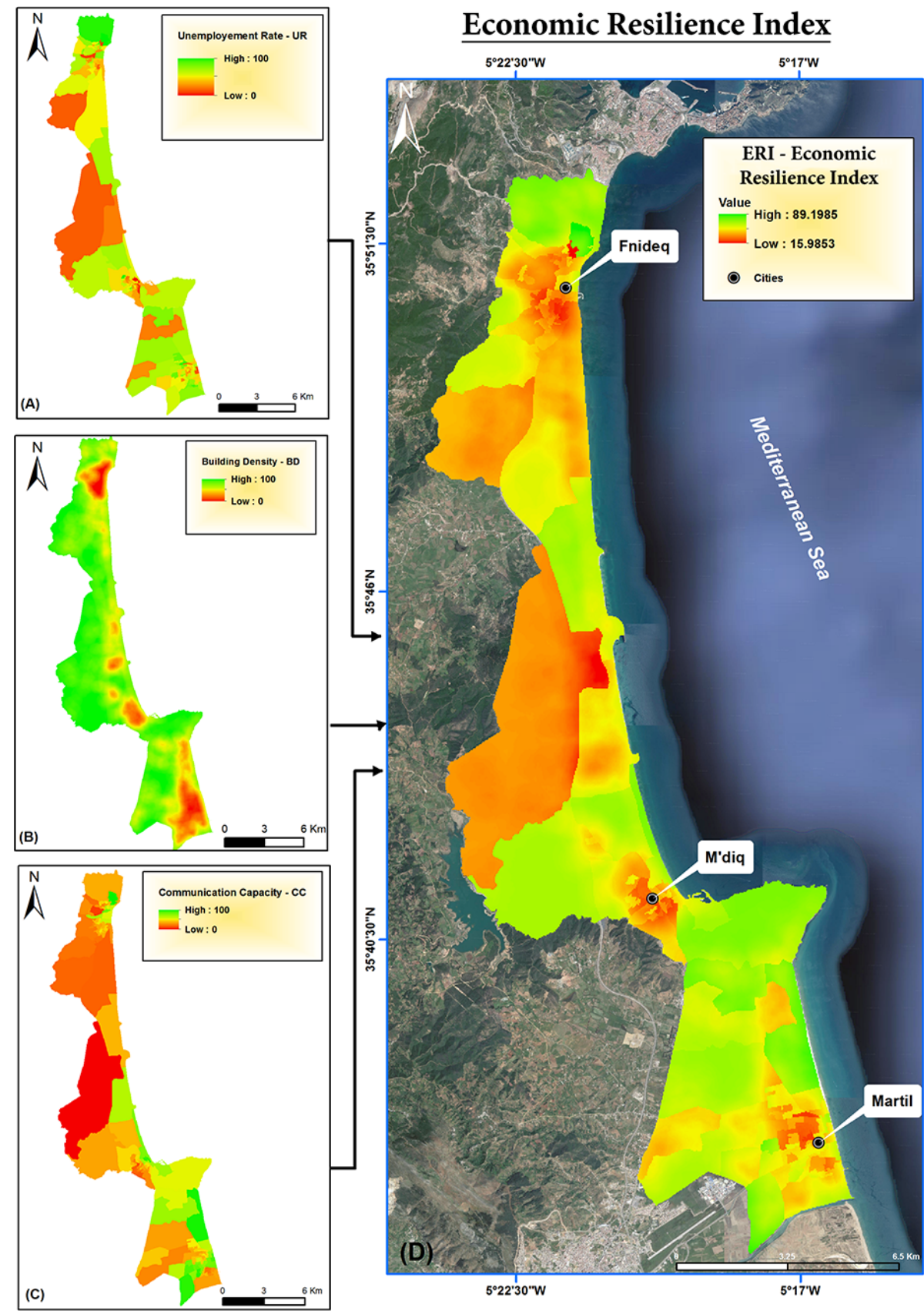

Figure 5. Spatial distribution of (a) unemployment rate, (b) building density in 2017, (c) communication capacity, and (d) economicresilience index (obtained from (c) Google Maps 2018).

eas, especially in terms of socioeconomics, highly influence the flood resilience index values.

In order to avoid any confusion related to flood management priorities between the rural and the urban areas, the resilience maps corresponding to urban areas were extracted, and the index values using GISs were reclassified to have the priority areas without taking into account the rural part. Using this tool to overlay the spatial distribution of households (RGPH, 2014) and the FRI map, it turns out that 1151 house- holds (around $2.4 \%$ ) are in areas of very low resilience and more than 7800 households (about 16\%) in low-resilience areas. On the other hand, 7402 households are in a highresilience situation, and only 177 can be qualified as having very high resilience (Fig. 8b). 

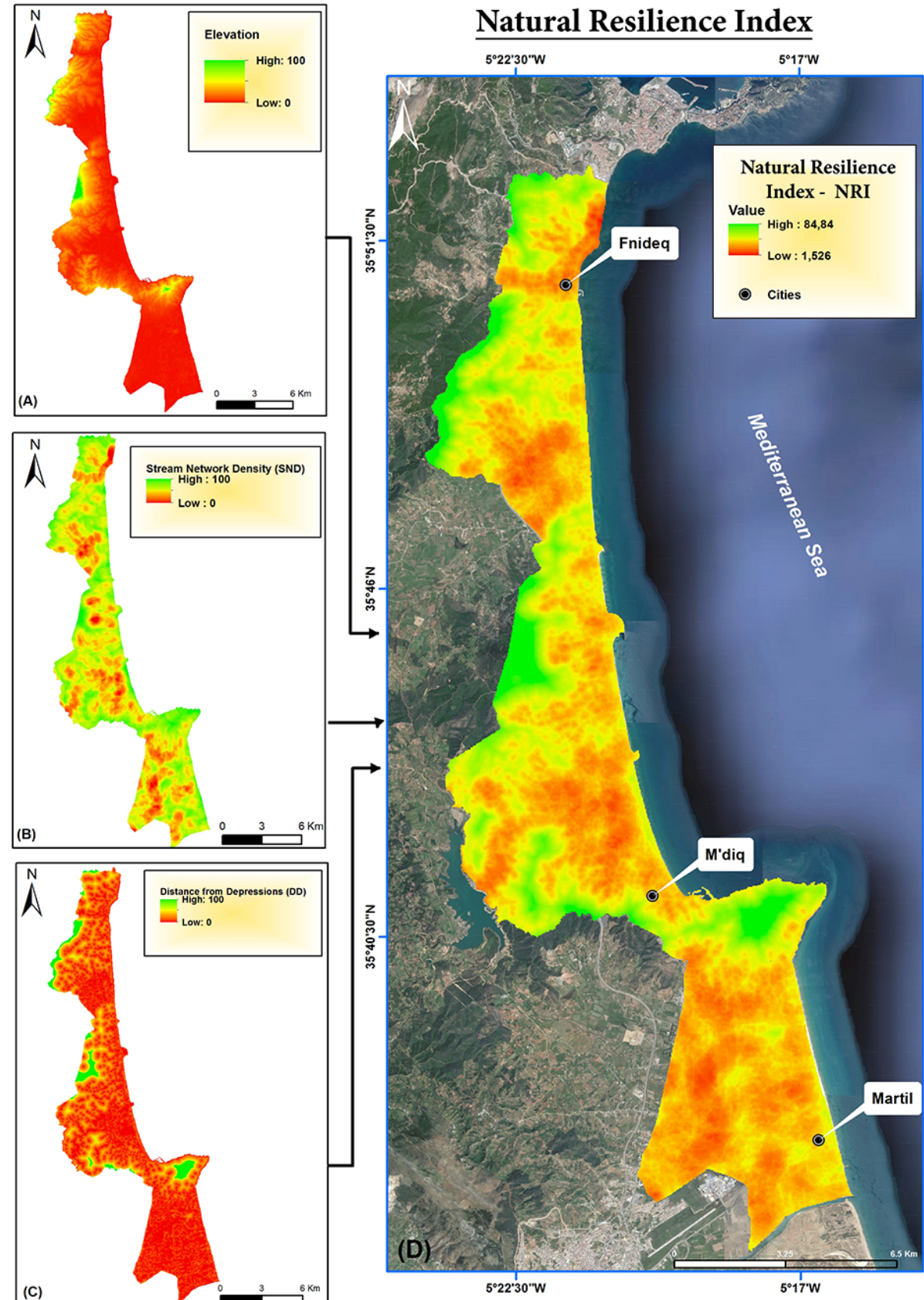

Figure 6. Spatial distribution of (a) elevation, (b) stream network density, (c) distance from depressions, and (d) natural-resilience index (obtained from (c) Google Maps 2018).

\subsection{Statistical analysis}

In order to evaluate the contribution of the sub-dimensions (social, economic, physical, and natural dimensions) for the resilience analysis, the statistical relationship between the total flood resilience index (FRI) and its sub-indices was estimated for each municipality (Table 2).

The SRI is positively correlated with the FRI in the three municipalities $(p<0.001)$, particularly in the urban areas, where it is proven to be important as an FRI component. Regarding the ERI sub-index, it shows a moderate correlation in the Fnideq and Martil municipalities $(p<0.01)$ or even a low correlation at the M'diq level $(p<0.05)$. Unlike the SRI and ERI, the correlation with the PRI sub-index is different from one municipality to another. It is strong at the level of Martil $(p<0.001)$, weak at the level of Fnideq $(p<0.01)$, and absent at the level of M'diq. In the case of the NRI sub- 


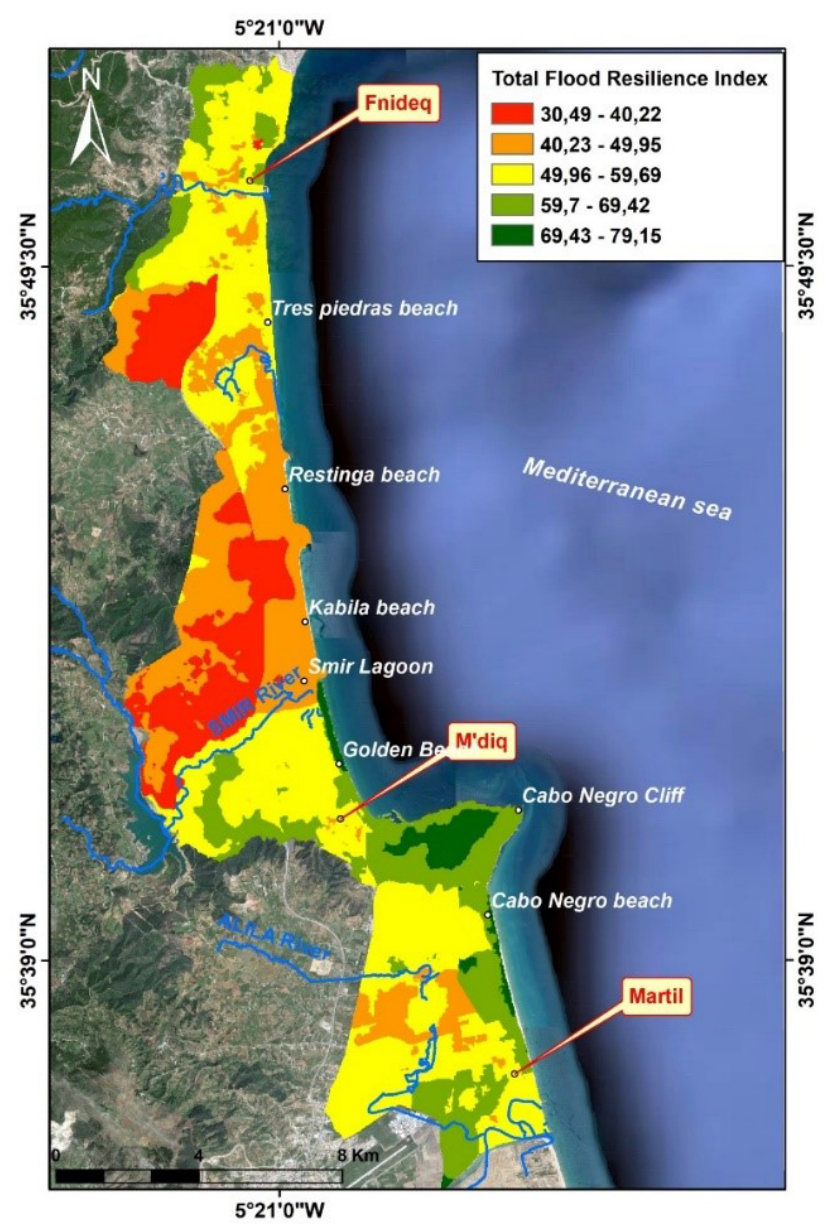

Figure 7. Distribution of total flood resilience index (obtained from (C) Google Maps 2018).

Table 2. Spearman's rho correlation between the total flood resilience index (FRI) and its dimensions.

\begin{tabular}{rlrrrr}
\hline & & SRI & ERI & PRI & NRI \\
\hline \multirow{2}{*}{ FRI } & Fnideq & $0.643^{* * *}$ & $0.441^{* *}$ & $0.378^{*}$ & $0.650^{* * *}$ \\
& Martil & $0.764^{* * *}$ & $0.425^{* *}$ & $0.589^{* * *}$ & $0.470^{* *}$ \\
& M'diq & $0.800^{* * *}$ & $0.408^{*}$ & - & $0.544^{* *}$ \\
\hline
\end{tabular}

${ }^{*} p<0.05 ;{ }^{* *} p<0.01 ;{ }^{* * *} p<0.001$.

index, it displays a strong correlation at the level of Fnideq and moderate at the level of Martil and M'diq.

\section{Discussion}

Within the current context of global climate change associated with an increase in flood damage, the efficient use of available data is, in most cases, the primary source of judgement control in decision-making for flood risk management (Ouma and Tateishi, 2014). Producing flood resilience maps has thus become a crucial issue for local flood management planners (Godschalk, 2003). However, these products require generally detailed knowledge about all resilience components in time and space to be effective. They should be designed in such a way that can help the decision-making by using the ranking and prioritization process (Chitsaz and Banihabib, 2015). Accordingly, the choice of a good methodology to assess and quantify resilience attains its utmost importance and relevance. Indeed, the adopted methodological approach as well as the quality of the data has a significant influence on the obtained results and hence on the final decision-making (Suárez et al., 2016).

In this paper, the adopted methodology is adaptable according to the study case and the available data. Moreover, the adapted ranking process is based on linear scoring, which offers the advantage of being more sensitive to changes compared to the usual methods based on assigning scores according to intervals (e.g. Angeon and Bates, 2015). It also provides a more reliable and objective spatial comparison of resilience parameter values, which will finally allow effective prioritization of resilient areas to be obtained.

It should be noted that significant components for the resilience analysis have been considered and the obtained resilience map allowed the classification of the study area according to four resilience degrees to floods: very low, low, moderate, and high.

The difference in the social-resilience sub-index between urban and rural areas could be explained by the fact that human development indicators are generally lower in rural and less developed areas, especially those related to school attendance and people's vulnerability, which affect social resilience negatively. However, the difference in the SRI between municipalities may occur because of the great growth rate of Martil municipality rather than Fnideq and M'diq (HCP, 2018)

The low physical resilience in the central area and the less developed sectors may exist because of the low population and urbanization (e.g. at the central-area access to water infrastructure) as basic service is still low (Fig. 4c), unlike in the case of the urban centres with high physical-resilience scores.

Meanwhile, the high level of the economic-resilience subindex in some coastal urban sectors may be explained by tourism and economic activities. An expected result has given the characteristics of the wealthy residents living there (Tempelhoff et al., 2009; Kotzee et Reyers, 2016), unlike the three urban centres having low and moderate economic resilience that could be explained by the high unemployment rate of $17.9 \%$ (HCP, 2018) and the high urban density. These results support our hypotheses and the suggestions from Cutter et al. (2010) and Hung et al. (2016). Further, the results of Irajifar et al. (2016) show that the association of high population density and high incomes makes a recovery after disaster quicker. 

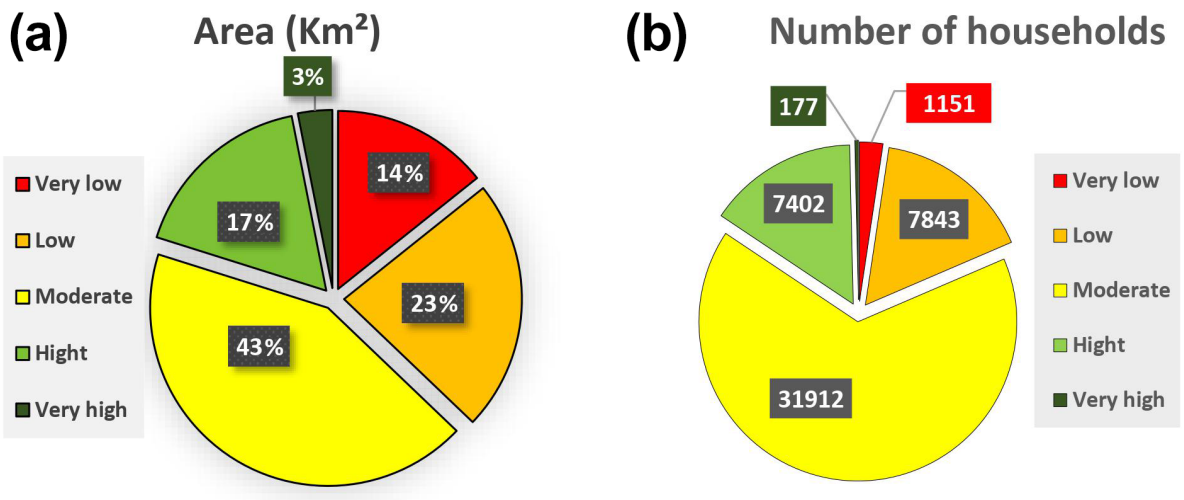

Figure 8. (a) Total flood resilience score distribution according to the surface of the study area; (b) total flood resilience score distribution according to household numbers in the study area.

The overall picture of natural resilience shows that all three municipalities have lower natural resilience. Martil had a somewhat low level of the NRI as compared to Fnideq and M'diq. This is because of the lowest values of elevation indicator and distance from depressions. The findings fully correspond to the existing literature (Hung et al., 2016), supporting the relationship between elevation, flood-prone areas, and the least resilience.

The areas with a very low and low flood resilience index seem to be generally associated with the areas showing unstable socials conditions. This observation is confirmed by the statistical analysis and studies (Godschalk, 2003; Cutter et al., 2010; Kotzee et Reyers, 2016; Moghadas et al., 2019) showing that social resilience is strongly correlated with flood resilience degree. Moreover, the disparities highlighted between rural and urban areas revealed that rural areas display the lowest resilience to floods.

The natural resilience, which is tightly linked at the sites, is the second-most statistically significant indicator linked to the total FRI. Disparities between municipalities are less significant. This means that areas having low or moderate resilience to floods need equal attention (Qasim et al., 2016).

The risk- and vulnerability-oriented studies (Niazi, 2007; Snoussi et al., 2011; Nejjari, 2014; Satta et al., 2016) in the coastal area were used for validation. The results are consistent, showing that coastal sites such as Restinga plain, Kabila beach, Smir lagoon, and Martil-Alila plain, which have a low resilience, are highly vulnerable to the flash floods and sealevel-rise impacts (Snoussi et al., 2011; Niazi, 2007; Satta et al., 2016). Considering all the output, this confirms that the flood resilience index is relatively valid and can be adapted and tested in other geographical areas. Moreover, this robustness analysis makes the FRI in this case of study support the idea that areas with higher vulnerability levels have lower resilience levels (Hung et al., 2016).

In this context, there is a need to prioritize the actions contributing to enhancing the social and economic communities' levels to provide support and strengthen actions promoting social and economic levels in the municipalities.

Further, the statistical analysis shows a significant link between the natural characteristics and resilience degrees. In that situation, it is recommended to establish best practices and measures to avoid urban development in flooded areas and to provide more efforts to manage the risk of floods in urbanized areas, with a strong focus on the contingency plans in case of power or drinking water failure in the three municipalities.

Therefore, there is a need to incorporate disaster management education in college to explain hazard adaptation and to educate people through communication devices, seminars, and workshops to make citizens aware of the damages and the climate change effects.

The obtained results highlight the importance of using a multidimensional approach to assess flood resilience. Furthermore, GISs are also highly recommended as a solution to complex situations and as a decision-support tool that offers an interactive use and continued improvement (Ouma and Tateishi, 2014; Mayunga, 2007).

\section{Conclusions}

Building and enhancing resilience to floods become critical as the urban development in a coastal area in Africa is increasingly stressed, especially for the coastal zones situated in semi-arid threatened areas, as in Morocco's local contexts, where this study is the first attempt at focusing on enhancing the understanding of resilience to floods and highlighting the application of the tangible approach to summarize and present complex components linked to resilience to floods.

Flood resilience assessment was piloted using a composite index and geographic information systems. The spatial and statistical analysis gave further insights into the geographic distribution of the flood resilience index across Fnideq, M'diq, and Martil municipalities. Moreover, the in- 
dex clarifies the presentation of a complex set of components linked in a reproducible way.

The findings indicate that different factors can affect spatial patterns of resilience to floods. The framework is flexible enough to allow the proposed index, in future work, to take into consideration the institutional component. Including the institutional component could advance our understanding of flood resilience and provide useful results to suggest flood adaptation strategies in a coastal area. The robustness of the flood resilience indicator was tested by comparing the results against additional case studies and operationalized resilience measures. Some of the main limitations of the developed flood resilience index are starting with tackling the main limitations from considering real and simulated flood inundation maps and integrating climatic data (flood data or flood simulation data). Besides, for robust validation, the date of resilience assessment and validation tool date should be highlighted to take the specific changes in land covers between the two periods of time into account. Further work will use other methodologies for developing the flood resilience index in the same coastal area to provide further insights into indicator assessments and the relationships among flood resilience and flood risk.

Data availability. To get the data, the request is directed to the "HCP - Haut-Commissariat Au Plan" https://www.hcp.ma/ (last access: 22 March 2021) (HCP, 2021) via direct deposit upon presentation of the deposit receipt or by sending a request through http: //www.chafafiya.ma/demande.php (last access: 22 March 2021).

Author contributions. NS prepared the paper with contributions from all co-authors. NS and OR designed the study. OR carried out the computational experiments. NS investigated and visualized the results and developed the statistical analysis. NS wrote the manuscript with support from NEM and OR. NEM added crucial suggestions to the paper and contributed to the editing and revision of the manuscript. IK and NK supervised the project. All authors approved the final publication.

Competing interests. The authors declare that they have no conflict of interest.

Acknowledgements. The authors would like to thank the Office of the High Commission for Planning (HCP) and the Hydraulic Basin Agency of Loukkos in Morocco for making their data available for our study. We acknowledge the inputs from the reviewers (including Jorge Leandro) and the editor as they have been very helpful in improving the quality of the present work. Special thanks are to Mohamed Ben-Daoud, Mounir Ouzir, and Khalid Margaa for their meaningful insights provided.
Review statement. This paper was edited by Kai Schröter and reviewed by Jorge Leandro and two anonymous referees.

\section{References}

ABHL: Hydraulic Basin Agency of Loukkos, Typology and inventory of sites at flloding risk ABHL, 2, available at: http://www. abhloukkos.ma/abhl/index.php/fr/ (last access: March 2021), 2016.

Adger, W. N., Hughes, T. P., Folke, C., Carpenter, S. R., and Rockström, J.: Social-Ecological Resilience to Coastal Disasters, Science, 309, 1036-1039, https://doi.org/10.1126/science.1112122, 2005.

Ahern, J.: From fail-safe to safe-to-fail: Sustainability and resilience in the new urban world, Landsc. Urban Plan., 100, 341-343, https://doi.org/10.1016/j.landurbplan.2011.02.021, 2011.

Andersson, E,: Urban landscapes and sustainable cities, Ecol. Soc., 11, 34, available at: http://www.ecologyandsociety.org/vol11/ iss1/art34/ (last access: 22 March 2021), 2006.

Anfuso, G., Martinez, J. A., and Nachite, D.: Coastal vulnerability in the Mediterranean sector between Fnideq and M'diq (North of Morocco). Co Ren de l'Aca bulgare des Sci, Géophy. Géomo., 63, 561-570, 2010.

Angeon, V. and Bates, S.: reviewing composite vulnerability and resilience indexes: A sustainable approach and application, World Dev., 72, 140-162, https://doi.org/10.1016/j.worlddev.2015.02.011, 2015.

Asadzadeh, A., Kötter, T., Salehi, P., and Birkmann, J.: Operationalizing a concept: The systematic review of composite indicator building for measuring community disaster resilience, Int. J. Dis. Risk Reduct., 25, 147-162, https://doi.org/10.1016/j.ijdrr.2017.09.015, 2017.

Bahir, M., Ouhamdouch, S., Ouazar, D., and El Moçayd, N.: Climate change effect on groundwater characteristics within semiarid zones from western Morocco, Groundwater Sustain. Dev., 11, 100380, https://doi.org/10.1016/j.gsd.2020.100380, 2020.

Barthel, P. A. and Planel, S.: Tanger-Med and Casa-Marina, prestige projects in Morocco: new capitalist frameworks and local context, Built Environ., 36, 176-191, https://doi.org/10.2148/benv.36.2.176, 2010.

Bates, B. C., Kundzewicz, Z. W., Wu, S., and Palutikof, J. P. (Eds.): Climate Change and Water, Technical Paper of the Intergovernmental Panel on Climate Change, IPCC Secretariat, Geneva, 210 pp., ISBN 978-92-9169-123-4, 2008.

Batica, J.: Methodology for flood resilience assessment in urban environments and mitigation strategy development, Diss. Université Nice Sophia Antipolis, 2015.

Bertilsson, L., Wiklund, K., de Moura Tebaldi, I., Rezende, O. M., Veról, A. P., and Miguez, M. G.: Urban flood resilience - A multi-criteria index to integrate flood resilience into urban planning, J. Hydrol., 573, 970-982, https://doi.org/10.1016/j.jhydrol.2018.06.052, 2019.

Born, K., Fink, A. H., and Paeth, H.: Dry and wet periods in the northwestern Maghreb for present day and future climate conditions, Meteorol. Z., 17, 533-551, https://doi.org/10.1127/09412948/2008/0313, 2008.

Cai, H., Lam, N. S., Qiang, Y., Zou, L., Correll, R. M., and Mihunov, V.: A synthesis of disaster resilience measurement 
methods and indices, Int. J. Disast. Risk Reduct., 31, 844-855, https://doi.org/10.1016/j.ijdrr.2018.07.015, 2018.

Cardoso, M. A., Brito, R. S., Pereira, C., Gonzalez, A.. Stevens, J., and Telhado, M. J.: RAF Resilience Assessment Framework - A Tool to Support Cities' Action Planning, Sustainability, 12, 2349, https://doi.org/10.3390/su12062349, 2020.

Cariolet, J. M., Vuillet, M., and Diab, Y.: Mapping urban resilience to disasters - A review, Sustain. Cities Soc., 51, 101746, https://doi.org/10.1016/j.scs.2019.101746, 2019.

Carpenter, S., Walker, B., Anderies, J. M., and Abel, N.: From metaphor to measurement: resilience of what to what?, Ecosystems, 4, 765-781, https://doi.org/10.1007/s10021-001-0045-9, 2001.

Chang, P. G. and Jeon, B. H.: The usage of traditional roof frame and fire prevention design in the Deajojeon Complex reconstruction in Changdeokgung during the period from 1917 to 1921, J. Architect. Inst. Korea Plan. Design, 30, 153-164, 2014.

Chen, K. F. and Leandro, J.: A conceptual time-varying flood resilience index for urban areas: Munich city, Water, 11, 830, https://doi.org/10.3390/w11040830, 2019.

Chen, N. and Graham, P.: Climate change as a survival strategy: soft infrastructure for urban resilience and adaptive capacity in Australia's coastal zones, in: Resilient Cities, Springer, Dordrecht, 379-388, https://doi.org/10.1007/978-94-007-0785-6_38, 2011.

Chitsaz, N. and Banihabib, M. E.: Comparison of different multi criteria decision-making models in prioritizing flood management alternatives, Water Resour. Manage., 29, 2503-2525, https://doi.org/10.1007/s11269-015-0954-6, 2015.

Cohen, R., Erez, K., Ben-Avraham, D., and Havlin, S.: Resilience of the internet to random breakdowns, Phys. Rev. Lett., 85, 4626, https://doi.org/10.1103/PhysRevLett.85.4626, 2000.

Colding, J. and Barthel, S.: The potential of 'Urban Green Commons' in the resilience building of cities, Ecolog. Econ., 86, 156166, https://doi.org/10.1016/j.ecolecon.2012.10.016, 2013.

Conway, G.: The science of climate change in Africa: impacts and adaptation, Grantham Institute for Climate Change Discussion Paper 1, available at: http://www.ask-force.org/web/Global-Warming/ Convay-Science-Climate-Change-Africa-2008.pdf (last access: March 2021), 2009.

CRED - Centre for Research on the Epidemiology of Disasters: News letter, Crunch 56 - Disasters in Africa: 20 Year Review (2000-2019), available at: https://www.emdat. be/publications (last access: 22 March 2021), 2019.

Cretney, R.: Resilience for Whom? Emerging Critical Geographies of Socio-ecological Resilience, Geogr. Compass, 8/9, 627-640, https://doi.org/10.1111/gec3.12154, 2014.

Cutter, S. L., Barnes, L., Berry, M., Burton, C., Evans, E., Tate, E., and Webb, J.: A place-based model for understanding community resilience to natural disasters, Global Environ. Change, 18, 598-606, https://doi.org/10.1016/j.gloenvcha.2008.07.013, 2008.

Cutter, S. L., Burton, C. G., and Emrich, C. T.: Disaster resilience indicators 517 for benchmarking baseline conditions, J. Homeland Secur. Emerg. Manage., 7, 51, https://doi.org/10.2202/15477355.1732, 2010.

Cutter, S. L., Ash, K. D., and Emrich, C. T.: The geographies of community disaster resilience. Global Environ. Change, 29, 6577, https://doi.org/10.1016/j.gloenvcha.2014.08.005, 2014.
Disse, M., Johnson, T. G., Leandro, J., and Hartmann, T.: Exploring the relation between flood risk management and flood resilience, Water Secur., 9, 100059, https://doi.org/10.1016/j.wasec.2020.100059, 2020.

Doocy, S., Daniels, A., Packer, C., Dick, A., and Kirsch, T. D.: The human impact of earthquakes: a historical review of events 19802009 and systematic literature review, PLoS Currents, 5, ecurrents.dis.67bd14fe457f1db0b5433a8ee20fb833, 2013.

Driouech, F., Déqué, M., and Mokssit, A.: Numerical simulation of the probability distribution function of precipitation over Morocco, Clim. Dynam., 32, 1055-1063, https://doi.org/10.1007/s00382-008-0430-6, 2009.

Driouech, F., Déqué, M., and Sánchez-Gómez, E.: Weather regimes - Moroccan precipitation link in a regional climate change simulation, Global Planet. Change, 72, 1-10, https://doi.org/10.1016/j.gloplacha.2010.03.004, 2010.

Ducruet, C., Mohamed-Chérif, F., and Cherfaoui, N.: Maghreb port cities in transition: the case of Tangier, Portus Plus, available at: http://www.reteonline.org (last access: 22 March 2021), 2011.

El Moçayd, N., Kang, S., and Eltahir, E. A. B.: Climate change impacts on the Water Highway project in Morocco, Hydrol. Earth Syst. Sci., 24, 1467-1483, https://doi.org/10.5194/hess-24-14672020, 2020.

Esty, D. C., Levy, M., Srebotnjak, T., and De Sherbinin, A.: Environmental sustainability index: Benchmarking national environmental stewardship, Yale Center for Environmental Law \& Policy, New Haven, 47-60, https://doi.org/10.1017/S1355770X05002275, 2005.

Fisher, M., Abate, T., Lunduka, R. W., Asnake, W., Alemayehu, Y., and Madulu, R. B.: Drought tolerant maize for farmer adaptation to drought in sub-Saharan Africa: Determinants of adoption in eastern and southern Africa, Climatic Change, 133, 283-299, https://doi.org/10.1007/s10584-015-1459-2, 2015.

Folke, C., Carpenter, S., Elmqvist, T., Gunderson, L., Holling, C. S., and Walker, B.: Resilience and sustainable development: building adaptive capacity in a world of transformations, Ambio, 31, 437-440, https://doi.org/10.1579/0044-7447-31.5.437, 2002.

Freudenberg, M.: Indicateurs composites de performances des pays: Examen critique, Documents de travail de l'OCDE sur la science, la technologie et l'industrie, no. 2003/16, Éditions OCDE, Paris, https://doi.org/10.1787/405566708255, 2003.

Gaillard, J. C.: Vulnerability, capacity and resilience: perspectives for climate and development policy, J. Int. Dev., 22, 218-232, https://doi.org/10.1002/jid.1675, 2010.

Giorgi, F. and Lionello, P.: Climate change projections for the Mediterranean region, Global Planet. Change, 63, 90-104, https://doi.org/10.1016/j.gloplacha.2007.09.005, 2008.

Godschalk, D. R.: Urban hazard mitigation: creating resilient cities, Nat. Hazards Rev., 4, 136-143, https://doi.org/10.1061/(ASCE)1527-6988(2003)4:3(136), 2003.

Greco, S., Ishizaka, A., Tasiou, M., and Torrisi, G.: On the methodological framework of composite indices: A review of the issues of weighting, aggregation, and robustness, Social Indicat. Res., 141, 61-94, https://doi.org/10.1007/s11205-017-1832-9, 2019.

HCP - Haut-Commissariat Au Plan: Monographie de la préfecture de M'diq-Fnideq, Direction régionale de Tanger, Tétouan-al Hoceima, Kingdoom of Morocco, 2018. 
HCP - Haut-Commissariat Au Plan: https://www.hcp.ma/, last access: 22 March 2021.

Heinzlef, C., Becue, V., and Serre, D.: Operationalizing urban resilience to floods in embanked territories-Application in Avignon, Provence Alpes Côte d'azur region, Safety Sci., 118, 181193, https://doi.org/10.1016/j.ssci.2019.05.003, 2019.

Hinkel, J.: "Indicators of vulnerability and adaptive capacity": towards a clarification of the science - policy interface, Global Environ. Change, 21, 198-208, https://doi.org/10.1016/j.gloenvcha.2010.08.002, 2011.

Hoffman, T. and Vogel, C.: Climate change impacts on African rangelands, Rangelands, $\quad 30, \quad 12-17, \quad$ https://doi.org/10.2111/1551501X(2008)30[12:CCIOAR]2.0.CO;2, 2008.

Holling, C. S.: Resilience and stability of ecological systems, Annu. Rev. Ecol. System., 4, 1-23, 1973.

Hung, H. C., Yang, C. Y., Chien, C. Y., and Liu, Y. C.: Building resilience: Mainstreaming community participation into integrated assessment of resilience to climatic hazards in metropolitan land use management, Land Use Policy, 50, 48-58, https://doi.org/10.1016/j.landusepol.2015.08.029, 2016.

IPCC: Summary for Policymakers, in: Climate Change 2007: Impacts, Adaptation and Vulnerability, Contribution of Working Group II to the Fourth Assessment Report of the Intergovernmental Panel on Climate Change, edited by: Parry, M. L., Canziani, O. F., Palutikof, J. P., Van der Linden, P. J., and Hanson, E. E., Cambridge University Press, Cambridge, UK, 7-22, 2007.

Irajifar, L., Sipe, N., and Alizadeh, T.: The impact of urban form on disaster resiliency: a case study of Brisbane and Ipswich, Australia, Int. J. Disast. Resil. Built Environ., 7, 3, https://doi.org/10.1108/IJDRBE-10-2014-0074, 2016.

Joerin, J., Shaw, R., Takeuchi, Y., and Krishnamurthy, R.: The adoption of a climate disaster resilience index in Chennai, India, Disasters, 38, 540-561, https://doi.org/10.1111/disa.12058, 2014.

Kanai, M. and Kutz, W.: Entrepreneurialism In The Globalising City-Region Of Tangier, Morocco, Tijdschrift voor economische en sociale geografie, 102, 346-360, https://doi.org/10.1111/j.1467-9663.2010.00622.x, 2011.

Karanja Ng'ang'a, S., Bulte, E. H., Giller, K. E., McIntire, J. M., and Rufino, M. C.: Migration and self-protection against climate change: a case study of Samburu County, Kenya, World Dev., 84, 55-68, https://doi.org/10.1016/j.worlddev.2016.04.002, 2016.

Karrouchi, M., Ouazzani, M., Touhami, M., Oujidi, M., and Chourak, M.: Mapping of flooding risk areas in the TangierTetouan region: Case of Martil Watershed (Northern Morocco), Int. J. Innov. Appl. Stud., 14, 1019-1035, 2016.

Klein, R. J., Nicholls, R. J., and Thomalla, F.: Resilience to natural hazards: How useful is this concept?, Global Environ. Change Pt. B, 5, 35-45, https://doi.org/10.1016/j.hazards.2004.02.001, 2003.

Kontokosta, C. E. and Malik, A.: The Resilience to Emergencies and Disasters Index: Applying big data to benchmark and validate neighborhood resilience capacity, Sustain. Cities Soc., 36, 272-285, https://doi.org/10.1016/j.scs.2017.10.025, 2018.

Kotzee, I. and Reyers, B.: Piloting a social-ecological index for measuring flood resilience: A composite index approach, Ecol. Indicat., 60, 45-53, https://doi.org/10.1016/j.ecolind.2015.06.018, 2016.
Kundzewicz, Z. W., Kanae, S., Seneviratne, S. I., Handmer, J., Nicholls, N., Peduzzi, P., Mechler, R., Bouweri, L. M., Arnell, N., Mach, K., Muir-Wood, R., Brakenridge, G. R., Kron, W., Benito, G., Honda, Y., Takahashi, K., and Sherstyukov, B.: Flood risk and climate change: global and regional perspectives, Hydrolog. Sci. J., 59, 1-28, https://doi.org/10.1080/02626667.2013.857411, 2014.

Leal Filho, W., Balogun, A. L., Ayal, D. Y., Bethurem, E. M., Murambadoro, M., Mambo, J., Taddese, H., Tefera, G. W., Nagy, G. J., Fudjumdjum, H., and Mugabe, P.: Strengthening climate change adaptation capacity in Africa-case studies from six major African cities and policy implications, Environ. Sci. Policy, 86, 29-37, https://doi.org/10.1016/j.envsci.2018.05.004, 2018.

Leandro, J., Chen, K. F., Wood, R. R., and Ludwig, R.: A scalable flood-resilience-index for measuring climate change adaptation: Munich city, Water Res., 173, 115502, https://doi.org/10.1016/j.watres.2020.115502, 2020.

Lutz, W. and Samir, K. C.: Dimensions of global population projections: what do we know about future population trends and structures?, Philos. T. Roy. Soc. B, 365, 2779-2791, https://doi.org/10.1098/rstb.2010.0133, 2010.

Marana, P., Eden, C., Eriksson, H., Grimes, C., Hernantes, J., Howick, S., Labaka, L., Latinos, V., Lindner, R., Majchrzak, T., Pyrko, I., Radianti, J., Rankin, A., Sakurai, M., Sarriegi, J. M., and Serrano, N.: Towards a resilience management guideline Cities as a starting point for societal resilience, Sustain. Cities Soc., 48, 101531, https://doi.org/10.1016/j.scs.2019.101531, 2019.

Mayunga, J. S.: Understanding and applying the concept of community disaster 603 resilience: a capital-based approach, Summer academy for social vulnerability and resilience building, available at: https://www.u-cursos.cl/usuario/ 3b514b53bcb4025aaf9a6781047e4a66/mi_blog/r/11._Joseph_ S._Maynga.pdf (last access: 22 March 2021), 2007.

Meerow, S., Newell, J. P., and Stults, M.: Defining urban resilience: A review, Landsc. Urban Plan., 147, 38-49, https://doi.org/10.1016/j.landurbplan.2015.11.011, 2016.

Miguez, M. G. and Veról, A. P.: A catchment scale Integrated Flood Resilience Index to support decision making in urban flood control design, Environ. Plan. B, 44, 925-946, https://doi.org/10.1177/0265813516655799, 2016.

Moghadas, M., Asadzadeh, A., Vafeidis, A., Fekete, A., and Kötter, T.: A multi-criteria approach for assessing urban flood resilience in Tehran, Iran, Int. J. Disast. Risk Reduct., 35, 101069 , https://doi.org/10.1016/j.ijdrr.2019.101069, 2019.

Mugume, S. N., Gomez, D. E., Fu, G., Farmani, R., and Butler, D.: A global analysis approach for investigating structural resilience in urban drainage, Water Res., 81, 16, https://doi.org/10.1016/j.watres.2015.05.030, 2015.

Nachite, D.: Le developpement touristique du littoral de la region Tanger-Tetouan: une evolution vers des scenarios non desirables?, in: Geología y Geoturismo en la Orilla Sur Del Estrecho De Gibraltar, edited by: Domínguez Bella, S. and Maate, A., MCN - UCA, Cadiz, 59-78, ISBN 978-84-9828-224-5, 2009.

Nejjari, A.: Vulnérabilité environnementale et planification urbaine, états des lieux: cas du littoral M'diq-F, Revue AFN, Maroc, 1214, 2014.

Nelson, D. R., Adger, W. N., and Brown, K.: Adaptation to environmental change: contributions of a resilience 
framework, Annu. Rev. Environ. Resour., 32, 395-419, https://doi.org/10.1146/annurev.energy.32.051807.090348, 2007.

Neumann, B., Vafeidis, A. T., Zimmermann, J., and Nicholls, R. J.: Future coastal population growth and exposure to sea-level rise and coastal flooding - a global assessment, PloS One, 10, e0118571, https://doi.org/10.1371/journal.pone.0118571, 2015.

Niazi, S.: Evaluation des impacts des changements climatiques et de l'élévation du niveau de la mer sur le littoral de Tétouan (Méditerranée occidentale du Maroc): Vulnérabilité et adaptation, $\mathrm{PhD}$ thesis, Mohamed V, Rabat, Maroc, available at: http://thesesenafrique.imist.ma/bitstream/handle/ 123456789/189/THESE_NIAZI.pdf?sequence=1 (last access: 22 March 2021), 2007.

OCDE - Organisation de coopération et de développement économiques: Rapport sur la gestion-des-risques-marocprincipaux-résultats, available at: https://www.oecd.org/fr/gov/ risques/gestion-des-risques-maroc-principaux-resultats.pdf (last access: 22 March 2021), 2016.

OECD: Handbook on Constructing Composite Indicators, Methodology and user guide, Paris CEDEX, France, p. 31, ISBN 97892-64-04345-9, 2008.

Ouhamdouch, S. and Bahir, M.: Climate change impact on future rainfall and temperature in semi-arid areas (Essaouira Basin, Morocco), Environ. Process., 4, 975-990, https://doi.org/10.1007/s40710-017-0265-4, 2017.

Ouma, Y. and Tateishi, R.: Urban flood vulnerability and risk mapping using integrated multi-parametric AHP and GIS: methodological overview and case study assessment, Water, 6, 15151545, https://doi.org/10.3390/w6061515, 2014.

Paeth, H., Hall, N. M., Gaertner, M. A., Alonso, M. D., Moumouni, S., Polcher, J., Ruti, P. M., Fink, A. H., Gosset, M., Lebel, T., Gaye, A. T., Rowell, D. P., Moufouma-Okia, W., Jacob, D., Rockel, B., Giorgi, F., and Rummukainen, M.: Progress in regional downscaling of West African precipitation, Atmos. Sci. Lett., 12, 75-82, https://doi.org/10.1002/asl.306, 2011.

Pagano, A., Pluchinotta, I., Giordano, R., and Vurro, M.: Drinking water supply in resilient cities: Notes from L'Aquila earthquake case study, Sustain. Cities Soc., 28, 435-449, https://doi.org/10.1016/j.scs.2016.09.005, 2017.

Pallard, B., Castellarin, A., and Montanari, A.: A look at the links between drainage density and flood statistics, Hydrol. Earth Syst. Sci., 13, 1019-1029, https://doi.org/10.5194/hess-13-1019-2009, 2009.

Papadopoulos, T., Gunasekaran, A., Dubey, R., Altay, N., Childe, S. J., and Fosso-Wamba, S.: The role of Big Data in explaining disaster resilience in supply chains for sustainability, J. Clean. Product., 142, 1108-1118, https://doi.org/10.1016/j.jclepro.2016.03.059, 2017.

Patel, S. S., Rogers, M. B., Amlôt, R., and Rubin, G. J.: What do we mean by "community resilience"? A systematic literature review of how it is defined in the literature, PLoS Currents, 9, 29188132, 2017

Paton, D., McClure, J., and Burgelt, P.: Natural Hazard Resilience: The Role of Individual and Household Preparedness, in: Disaster Resilience: An Integrated Approach, edited by: Thomas, C. C., Paton, D., and Johnston, D., Charles C. Thomas, Springfield, Ill., USA, 105-127, ISBN 0-398-07663-4, 2006.
Pelling, M.: The vulnerability of cities: natural disasters and social resilience, Earthscan, UK, USA, ISBN 1853838306, 2003.

Pendall, R., Foster, K. A., and Cowell, M.: Resilience and Regions: Building Understanding ofthe Metaphor, available at: https://escholarship.org/uc/item/4jm157sh (last access: 22 March 2021), 2007.

Perelli, C.: Case Study Morocco: Mediterranean Morocco, a Vulnerable Development Called into Question, in: Global Climate Change and Coastal Tourism. Recognizing Problems, Managing Solutions and Future Expectations, CABI International, Italy, ISBN 9781780648453 (ePDF), https://doi.org/10.1079/9781780648439.0000, 2018.

Pike, A., Dawley, S., and Tomaney, J.,: Resilience, adaptation and adaptability, Cambridge J. Reg. Econ. Soc., 3, 59-70, https://doi.org/10.1093/cjres/rsq001, 2010.

Plate, E. J.: Flood risk and flood management, J. Hydrol., 267, 2-11, https://doi.org/10.1016/S0022-1694(02)00135-X, 2002.

Price, R. A.: Climate change and stability in North Africa, K4D Helpdesk Report 242, Institute of Development Studies, Brighton, UK, available at: https://assets.publishing.service. gov.uk/media/5a7052bded915d266017b8aa/242_Climate_ change_and_stability_in_Northern_Africa.pdf (last access: 22 March 2021), 2017.

Qasim, S., Qasim, M., Shrestha, R. P., Khan, A. N., Tun, K., and Ashraf, M.: Community resilience to flood hazards in Khyber Pukhthunkhwa province of Pakistan, Int. J. Disast. Risk Reduct., 18, 100106, https://doi.org/10.1016/j.ijdrr.2016.03.009, 2016.

Redman, C. L.: Resilience theory in archaeology, Am. Anthropol., 107, 70-77, https://doi.org/10.1525/aa.2005.107.1.070, 2005.

Reghezza-Zitt, M., Lhomme, S., and Provitolo, D.: Defining Resilience: When the Concept Resists, in: Resilience Imperative, Elsevier, 1-27, https://doi.org/10.1016/B978-1-78548-0515.50001-2, 2015.

Reisi, M., Aye, L., Rajabifard, A., and Ngo, T.: Transport sustainability index: Melbourne case study, Ecol. Indicat., 43, 288-296, https://doi.org/10.1016/j.ecolind.2014.03.004, 2014.

RGPH - Recenssement Géneral de la Population et de l'Habitat: Population Légale Des Régions, Provinces Et Préfectures Du Royaume, Par Milieu, D'après Les Résultats Du RGPH 2014 (12 Régions), avaailable at: https://rgph2014.hcp. ma/downloads/Publications-RGPH-2014_t18649.html (last access: 22 March 2021), 2014.

Roy, P. T., El Moçayd, N., Ricci, S., Jouhaud, J.-C., Goutal, N., De Lozzo, M., and Rochoux, M. C.: Comparison of polynomial chaos and Gaussian process surrogates for uncertainty quantification and correlation estimation of spatially distributed openchannel steady flows, Stoch. Environ. Res. Risk A., 32, 1723 1741, https://doi.org/10.1007/s00477-017-1470-4, 2018.

Rus, K., Kilar, V., and Koren, D.: Resilience assessment of complex urban systems to natural disasters: a new literature review, Int. J. Disast. Risk Reduct., 31, 311-330, https://doi.org/10.1016/j.ijdrr.2018.05.015, 2018.

Saisana, M., Saltelli, A., and Tarantola, S.: Uncertainty and sensitivity analysis techniques as tools for the quality assessment of composite indicators, J. Roy. Statist. Soc. Ser. A, 168, 307-323, https://doi.org/10.1111/j.1467-985X.2005.00350.x, 2005.

Sanabria-Fernandez, J. A., Lazzari, N., and Becerro, M. A.: Quantifying patterns of resilience: What matters is the intensity, not the 
relevance, of contributing factors, Ecol. Indicat., 107, 105565, https://doi.org/10.1016/j.ecolind.2019.105565, 2019.

Satta, A., Snoussi, M., Puddu, M., Flayou, L., and Hout, R.: An index-based method to assess risks of climate-related hazards in coastal zones: The case of Tetouan, Estuar. Coast. Shelf Sci., 175, 93-105, https://doi.org/10.1016/j.ecss.2016.03.021, 2016.

Serre, D., Barroca, B., Balsells, M., and Becue, V.: Contributing to urban resilience to floods with neighbourhood design: the case of Am Sandtorkai/Dalmannkai in Hamburg, J. Flood Risk Manage., 11, S69-S83, https://doi.org/10.1111/jfr3.12253, 2018.

Sharifi, A. and Yamagata, Y.: On the suitability of assessment tools for guiding communities towards disaster resilience, Int. Disast. Risk Reduct., 18, 115-124, https://doi.org/10.1016/j.ijdrr.2016.06.006, 2016.

Sherrieb, K., Norris, F. H., and Galea, S.: Measuring capacities for community resilience, Social Indicat. Res., 99, 227-247, https://doi.org/10.1007/s11205-010-9576-9, 2010.

Snoussi, M., Ouchani, T., and Niazi, S.: Vulnerability Assessment of the Impact of Sea-level Rise and Flooding on the Moroccan Coast: the Case of the Mediterranean Eastern Zone, Estuar. Coast. Shelf Sci., 77, 206-213, https://doi.org/10.1016/j.ecss.2007.09.024, 2008.

Snoussi, M., Ouchani, T., Khouakhi, A., and Niang-Diop, I.: Impacts of sea-level rise on the Moroccan coastal zone: quantifying coastal erosion and flooding in the Tangier Bay, Geomorphology, 107, 32-40, https://doi.org/10.1016/j.geomorph.2006.07.043, 2009.

Snoussi, M., Niazi, S., Khouakhi, A., and Raji, O.: Climate change and sea-level rise: A GIS-Based vulnerability and impact assessment, the case of the moroccan coast, in: Geomatic Solutions for Coastal Environments Book, Nova Publishers, ISBN 978-161668-140-1, 2011.

Speth, P., Christoph, M., and Diekkrüger, B.: Impacts of global change on the hydrological cycle in West and Northwest Africa, Springer-Verlag, Berlin, Heidelberg, https://doi.org/10.1007/978-3-642-12957-5, 2010.

Suárez, M., Gómez-Baggethun, E., Benayas, J., and Tilbury, D.: Towards an urban resilience Index: a case study in 50 Spanish cities, Sustainability, 8, 774, https://doi.org/10.3390/su8080774, 2016.

Taouri, O., El Ghammat, A., Hilal, I., Stitou, J., Hassani Zerrouk, M., and Drraz, C.: Flood management: Case of the city of M'diq and Fnideq, J. Water Sci. Environ. Technol., 2, 259-264, 2017.
Tempelhoff, J., Hoag, H., Ertsen, M., Arnold, E., Bender, M., Berry, K., Fort, C., Pietz, D., Musemwa, M., Nakawo, M., Ur, J., van Dam, P., Melosi, M., Winiwarter, V., and Wilkinson, T.: Where has the water come from?, in: Water History, Springer, 1-8, https://doi.org/10.1007/s12685-009-0003-6, 2009.

Terink, W., Immerzeel, W. W., and Droogers, P.: Climate change projections of precipitation and reference evapotranspiration for the Middle East and Northern Africa until 2050, Int. J. Climatol., 33, 3055-3072, https://doi.org/10.1002/joc.3650, 2013.

Thornes, J. B.: Land degradation, in: The physical geography of the Mediterranean, edited by: Woodward, J. C., Oxford University Press, Oxford, 563-581, 2009.

Tuel, A. and Eltahir, E. A. B.: Why Is the Mediterranean a Climate Change Hot Spot?, J. Climate, 33, 5829-5843, https://doi.org/10.1175/JCLI-D-19-0910.1, 2020.

UNDRR - United Nations Office for Disaster Risk Reduction: Global Assessment Report on Disaster Risk Reduction, UNDRR, Geneva, Switzerland, 2019.

UN-Habitat: Cities at risk from rising sea levels, in: UN-Habitat, State of the World's Cities 2008/2009, Earthscan, London, 140 $155,2008$.

UN-Habitat: Habitat III, U. N.: Issue papers 22 - informal settlements, in: United Nations Conference on Housing and Sustainable Urban Development, New York, 2015.

UNISDR: Sendai Framework for Disaster Risk Reduction, available at: https://www.unisdr.org/we/coordinate/sendai-framework/ 2015, last access: 28 January 2016.

Vicuña, S., Dracup, J. A., and Dale, L.: Climate change impacts on two high-elevation hydropower systems in California, Climatic Change, 109, 151-169, https://doi.org/10.1007/s10584011-0301-8, 2011.

Walker, B., Holling, C. S., Carpenter, S. R., and Kinzig, A.: Resilience, adaptability and transformability in social-ecological systems, Ecol. Soc., 9, 2, available at: https://www.jstor.org/ stable/26267673 (last access: 22 March 2021), 2004.

Weichselgartner, J. and Kelman, I.: Challenges and opportunities for building urban resilience, A/Z ITU J. Facul. Architect., 11, 20-35, 2014.

Westphal, M. and Bonanno, G. A.,: Posttraumatic growth and resilience to trauma: Different sides of the same coin or different coins?, Appl. Psychol., 56, 417-427, https://doi.org/10.1111/j.1464-0597.2007.00298.x, 2007. 